\title{
Amaranth bran powder is a promising raw material for the confectionery industry
}

\author{
Svetlana Khasanova, and Zinaida Skobelskaya \\ Moscow State University of Food Production, Volokolamskoe sh., 11, 125080 Moscow, Russia
}

\begin{abstract}
The research is devoted to the creation of a new raw material - a product of processing amaranth seeds of the species Amaranthus L. (variety "Krepysh", selection of FNTSO). Developed amaranth bran powder, which is a waste product in the production of oil from seeds. The bran contains $19.6 \%$ proteins, including water-soluble ones; $17.9 \%$ dietary fiber; $46.9 \%$ highly dextrinated starch; $1.01 \%$ of macro- and microelements, including deficient selenium. The selenium content in the studied batches of amaranth bran is $0.053 \mathrm{mg} \%$ per $100 \mathrm{~g}$ of dry weight, which allows us to meet the average daily human need for selenium by $70 \%$. The new technology includes infrared processing, bran cooling and fine grinding. Infrared processing allows targeted action on protein and carbohydrate complexes, increasing the biological value of amaranth bran powder, imparting increased moisture absorption properties to the product, and maintaining high quality indicators. Amaranth bran powder was stored at a temperature of $18 \pm 2^{\circ} \mathrm{C}$, relative air humidity $75 \pm 1^{\circ} \mathrm{C}$, in the presence of photocatalytic air purifiers "Tiokraft M-400". A new product - amaranth bran powder is recommended for use in the production of sugar and flour confectionery products
\end{abstract}

\section{Introduction}

In modern conditions, the most important task for the enterprises of the confectionery industry is to increase the output of competitive products. For this, in particular, new raw materials. [1]

In the confectionery industry of our country, special attention is paid to enrichment with functional ingredients and biologically active ingredients. The development of such products is carried out in accordance with the concept of healthy nutrition, which is aimed at maintaining and strengthening the health of the population, as well as preventing diseases caused by unbalanced nutrition. [2].

The development of plant-based powders provides an expansion of raw materials for the industry and an increase in the range of finished products. $[3,4,5]$

The work was carried out at the Federal State Budgetary Educational Institution of Higher Education "Moscow State University of Food Production". The research was carried out in order to develop a technology for obtaining a new raw material for the confectionery industry - amaranth bran powder, which is a secondary product in the production of amaranth oil using short-wave infrared radiation and a shock-pin disintegrator. 


\section{Methods and types of research on the properties of amaranth bran powder and products based on it}

In the work, we used a batch of bran from seeds of amaranth of the species Amaranthus L., variety "Krepysh", selection of the Federal State Budgetary Scientific Institution "Federal Scientific Center for Vegetable Growing. bran is a fat-free seed part of amaranth with a rich chemical composition, so it can also be used in the confectionery industry. [6,7,8].

Such processing of amaranth bran allows a gentle and targeted effect on protein and carbohydrate complexes, to increase its biological value, to impart moisture absorption properties to the product and maintain high quality indicators.

The thermally treated and ground powder of amaranth bran was stored in accordance with the current regulatory and technical requirements for bulk products: temperature $18 \pm 2 \pm \mathrm{C}$, relative air humidity $\Psi=75 \pm 1^{\circ} \mathrm{C}$.

Powder of amaranth bran was stored under conditions with additional air purification by medical photocatalytic installations "Tiokraft-M400".

\section{Analysis of the main results of research on the properties of amaranth bran powder and products based on it}

The composition of the native amaranth bran is presented in Table 1.

The studied bran contains $19.6 \%$ proteins, including soluble ones; $17.9 \%$ dietary fiber; $46.9 \%$ highly dextrinated starch; $1.01 \%$ of macro and microelements, including deficient selenium. The selenium content in the test batch of bran is $0.053 \mathrm{mg}$ per $100 \mathrm{~g}$ of dry matter. This is enough to meet the daily requirement of a person by $70 \%$. A new product - amaranth bran powder is recommended for use in the production of sugar and flour confectionery products.

Table 1. Physicochemical indicators of the quality of amaranth bran

\begin{tabular}{|c|c|c|}
\hline \multirow{2}{*}{ Main factors } & \multicolumn{2}{|c|}{ Quality indicators of native amaranth bran } \\
\hline & from literary sources & experimental data \\
\hline \multicolumn{3}{|c|}{ Chemical composition: } \\
\hline Proteins, $\%$ & 19,2 & $19,6 \pm 1,2$ \\
\hline Fats, $\%$ & 0,6 & $0,4 \pm 0,1$ \\
\hline Starch, \% & 45,5 & $46,9 \pm 1,3$ \\
\hline Mono- and disaccharides, $\%$ & 2,8 & $0,9 \pm 0,1$ \\
\hline Alimentary fiber, $\%$ & 15,8 & $17,9 \pm 1,2$ \\
\hline Ash, \% & 3,0 & $1,04 \pm 0,2$ \\
\hline Sodium, mg & 8,2 & $10,1 \pm 1,2$ \\
\hline Potassium, mg & 535 & $528,0 \pm 5,2$ \\
\hline Calcium, mg & 145 & $242 \pm 2,5$ \\
\hline Magnesium, mg & 45 & $35,9 \pm 1,2$ \\
\hline Phosphorus, mg & 76 & $66 \pm 2,5$ \\
\hline Iron, mg & 35 & $26,0 \pm 1,1$ \\
\hline Selenium, mg & 0,108 & $0,050 \pm 0,01$ \\
\hline Tocopherol equivalent, $\mathrm{mg}$ & 1,70 & $1,70 \pm 0,1$ \\
\hline Vitamin C, mg & 8,0 & $8,0 \pm 0,5$ \\
\hline Energy value, kcal & 233,00 & $227,00 \pm 4,0$ \\
\hline \multicolumn{3}{|l|}{ Physical indicators: } \\
\hline Average particle size, $\mathrm{mcm}$ & 240 & 300 \\
\hline Moisture content, $\%$ & 13,10 & 13,26 \\
\hline Expiration date, months & 6,0 & 6,0 \\
\hline
\end{tabular}


A tendency towards intensive soil pollution is observed near large cities, and since amaranth belongs to plants with cumulative properties, experimental batches of Amaranth L. seed bran were studied for the content of heavy metals by inductively coupled plasma mass spectrometry (MS-IS) as a source of ions with a quadrupole mass analyzer and a discretedynode detector. The choice of the method is due to the high accuracy of determining the concentration of elements and individual isotopes in raw materials - at a level from hundredths of nanograms to hundreds of milligrams per liter. The results are shown in Table 2.

The content of cadmium, mercury and lead is within the normalized values; iodine, bismuth and arsenic were not found. The results of the study indicate the food safety of the new raw materials recommended for the confectionery industry and the favorable state of the soil conditions of the growing region.

Table 2. Toxic elements in amaranth bran

\begin{tabular}{|c|c|c|c|}
\hline & Element & $\begin{array}{c}\text { Content in the studied maranth } \\
\text { bran, } \mu \mathrm{g} / \mathrm{g}\end{array}$ & $\begin{array}{c}\text { Maximum Allowable Concentration in food bran } \\
\text { according to TR TS 021/211, mg /g, no more }\end{array}$ \\
\hline 1 & $\mathrm{Bi}$ & Not found & Unacceptable \\
\hline 2 & $\mathrm{As}$ & Not found & 0,2 \\
\hline 2 & $\mathrm{I}$ & Not found & 0,04 \\
\hline 3 & $\mathrm{Cd}$ & $0,02 \pm 0,003$ & 0,2 \\
\hline 4 & $\mathrm{Hg}$ & $<0,0036$ & 0,03 \\
\hline 5 & $\mathrm{~Pb}$ & $0,05 \pm 0,008$ & 1,0 \\
\hline
\end{tabular}

The native amaranth bran has a solid structure, a specific smell, and is difficult to grind. Its use in the production of confectionery products requires special training.

After heat treatment at the UTZ-4 unit with an infrared power drive, the bran particles become brittle and are effortlessly crushed to the required size on impact-pin disintegrators. Intense IR radiation of the UTZ-4 installation has the ability to influence the vibrations of atoms in biological polymers, cause resonance and destruction of molecules, causing thermal destruction of almost any grain raw material. [9]

The choice of a disintegrator unit for grinding amaranth bran is due to a number of advantages over other mills: high productivity (one unit replaces 4-5 eight-roll mills), compactness, high dispersion (the unit allows achieving a dispersion of $94 \%$ ).

Heat treatment at UTZ-4 also contributes to the disruption of the integrity of proteinstarch matrices in the endosperm of amaranth seeds, an increase in the availability of proteins to digestive enzymes, partial destruction and dextrinization of starch. After heat treatment and grinding of raw materials, moisture absorption properties increase by 1.8 times. [10,11]

The developed powder of amaranth bran is characterized by the following quality indicators: mass fraction of moisture $6.3 \pm 0.1 \%$; dispersion not less than $90.0 \%$ (average particle size 20-30 microns).

The principle of operation of the photocatalytic cleaner "Tiokraft M-400", in the presence of which samples of amaranth bran powder were stored, is based on the acceleration of chemical reactions with the combined action of a catalyst of titanium dioxide and ultraviolet radiation. The air is forced into the purifier, passes through ultraviolet lamps, which impart quantum energy of light to it. Then the air enters the lattice with a nanocrystalline catalyst titanium dioxide, where organic molecules are oxidized to carbon dioxide and water (Figure $1)$. 


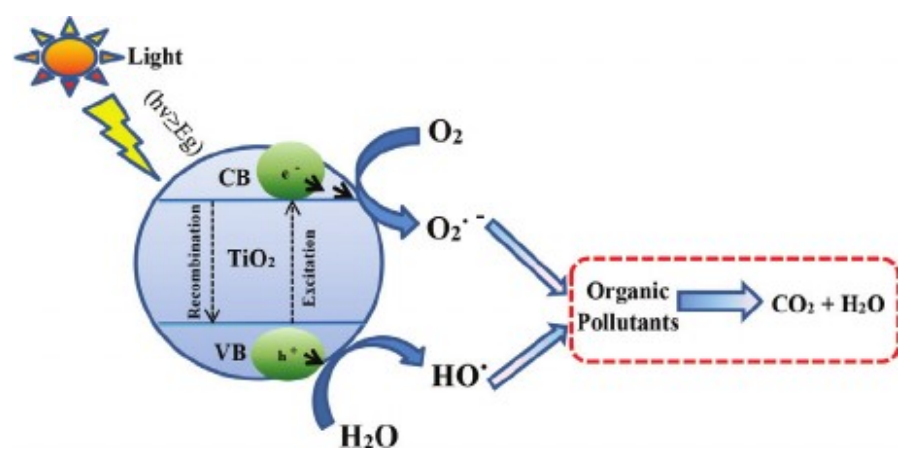

Fig.1 Principle of operation a photocatalytic air purifier works "Tiokraft M-400"

It was revealed that under such storage conditions it is possible to maintain a satisfactory microbiological state of amaranth bran powder for all standardized indicators in accordance with the requirements of the technical regulation of the Customs Union 022/2011 for 30 days (table 3).

Table 2. Microbiological parameters of amaranth bran powder during storage

\begin{tabular}{|c|c|c|c|c|c|}
\hline \multirow[b]{2}{*}{ № } & \multirow[b]{2}{*}{ Product } & \multirow[b]{2}{*}{ Storage conditions } & \multicolumn{3}{|c|}{ Indicators } \\
\hline & & & $\begin{array}{c}\text { NMAFA } \\
\text { M, } \\
\text { CEF/g, no } \\
\text { more } \\
\end{array}$ & $\begin{array}{c}\mathrm{CB}, \mathbf{g} / \mathbf{s m}^{3}, \\
\text { no more }\end{array}$ & $\begin{array}{c}\text { Mycelial } \\
\text { mushrooms } \\
, \text { CEF/g, no } \\
\text { more } \\
\end{array}$ \\
\hline 1 & $\begin{array}{c}\text { Food bran } \\
\text { (Norms } \\
\text { according to TR } \\
\text { CU 021/211) }\end{array}$ & $\mathrm{t}=18 \pm 2^{\circ} \mathrm{C}, \phi=75 \%$ & $\begin{array}{l}5 \times 10^{3 *} \\
5 \times 10^{4 * *}\end{array}$ & 0,1 & 50 \\
\hline \multirow{2}{*}{2} & $\begin{array}{l}\text { maranth bran } \\
\text { powder. 1st day } \\
\text { of storage }\end{array}$ & $\mathrm{t}=18 \pm 2^{\circ} \mathrm{C}, \phi=75 \%$ & $1,1 \times 10^{3}$ & Not found & 40 \\
\hline & $\begin{array}{l}\text { Amaranth bran } \\
\text { powder. 1st day } \\
\text { of storage }\end{array}$ & $\begin{array}{c}\mathrm{t}=18 \pm 2^{\circ} \mathrm{C}, \phi=75 \% \\
\text { photocatalytic } \\
\text { cleaners }\end{array}$ & $1,1 \times 10^{3}$ & Not found & 40 \\
\hline \multirow{2}{*}{3} & $\begin{array}{l}\text { Amaranth bran } \\
\text { powder. 30th } \\
\text { day of storage }\end{array}$ & $\mathrm{t}=18 \pm 2^{\circ} \mathrm{C}, \phi=75 \%$ & $3,4 \times 10^{3}$ & Not found & 55 \\
\hline & $\begin{array}{l}\text { Amaranth bran } \\
\text { powder. 30th } \\
\text { day of storage }\end{array}$ & $\begin{array}{c}\mathrm{t}=18 \pm 2^{\circ} \mathrm{C}, \phi=75 \% \\
\text { photocatalytic } \\
\text { cleaners }\end{array}$ & $1,3 \times 10^{3}$ & Not found & 45 \\
\hline
\end{tabular}

Notes: *for baby food; ** for adult food.

To study the moisture absorption properties, samples of the powder and native amaranth bran were stored in three different rooms with low (56\%), medium (66\%), and high $(83 \%)$ relative air humidity. The results are shown in Figure 2.

The powder actively absorbs moisture from the ambient air: the higher the relative humidity during storage, the more intense the sorption. On the 10th day of storage, equilibrium humidity was established in all samples. The mass fraction of moisture in the native bran during storage at a relative humidity of $\varphi=56 \%$ practically did not change; at $\varphi$ $=66 \%$ and $83 \%$ changed insignificantly. In amaranth bran at $\varphi=56 \%$, the mass fraction of moisture after 10 days of storage increased by $41 \%$; at $\varphi=66 \%$ - by $75 \%$; at $\varphi=83 \%$ - by $80 \%$. 


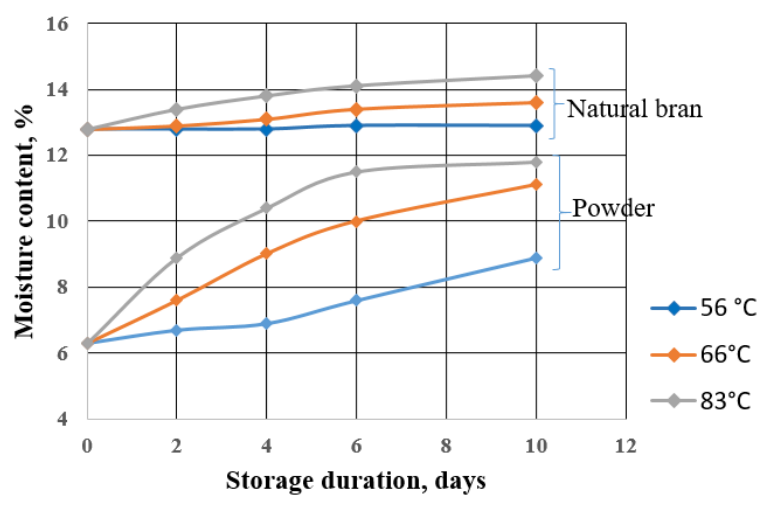

Fig.2. Dynamics of moisture sorption during storage of native bran and amaranth bran powder

Amaranth bran powder was used in the development of the technology of sweets with fondant bodies. The introduction of new raw materials into the recipe to improve the quality of sweets is a promising direction in the development of the confectionery industry. $[12,13]$.

Based on the results of the study, it was revealed that amaranth bran powder allows to increase the fraction of the fraction with crystal sizes of 10-15 microns, improve organoleptic characteristics. The bodies of the powdered chocolates had a uniform color, a uniform shiny surface, and a fine-crystalline structure.

On the 70th day of storage, candies with amaranth bran powder had an organoleptic rating higher than the control ones: sugar - by $16 \%$, fruit - 13\%, dairy - $8 \%$ (relative $\%$ ).

\section{Conclusions}

The basis for the creation of new raw materials for the confectionery industry is the use of a product of processing amaranth seeds - bran, followed by its processing with short-wave infrared radiation and grinding to a powdery state. Amaranth bran powder has a rich chemical composition and high moisture absorption properties. The composition of amaranth bran, its availability and low cost, makes it possible to recommend the use of this raw material in the production of sweets with fondant bodies, fillings for caramel, chocolate bars and flour confectionery

\section{References}

1. A. Kochetkova, Foods and Raw Materials, 20 (2020)

2. O. E. Bakumenko, Fortified food technology for target groups. Scientific foundations and technology (2013)

3. E. B. Alexeenko, Storage and processing of agricultural raw materials, 116 (2019)

4. I. A. Nikitin, International Journal of Pharmaceutical Research, 971 (2020)

5. Krasina I.B. American Journal of Biochemistry and Biotechnology, 99 (2014)

6. M. S. Gins, Bulletin AAS, 15 (2008)

7. M. Gins, Retirement, 330 (2018)

8. V. V. Kolpakova et al., Storage and processing of agricultural raw materials, 44 (2011)

9. V. V. Kirdyashkin, A.A. Andreeva, D.S. Bakhtina et al, Bakery products, 42 (2020)

10. S. D. Khasanova, Z. G. Skobelskaya, Confectionery production, 16 (2004) 
11. S. D. Khasanova, Z. G. Skobelskaya, Confectionery production, 40 (2005)

12. I. B. Krasina, U. F. Berestova et al, News of universities. Food technology, 62 (2006)

13. S. D. Khasanova, Z. G. Skobelskaya, A.U. Lebezova, Modification of the properties of amaranth bran for the confectionery industry (2017) 